\title{
Managing Foliar Blights on Carrot Using Copper, Azoxystrobin, and Chlorothalonil Applied According to TOM-CAST
}

\author{
E. A. Dorman, former Graduate Assistant, B. J. Webster, Research Assistant, and M. K. Hausbeck, Professor, \\ Michigan State University, East Lansing 48824-1311
}

\begin{abstract}
Dorman, E. A., Webster, B. J., and Hausbeck, M. K. 2009. Managing foliar blights on carrot using copper, azoxystrobin, and chlorothalonil applied according to TOM-CAST. Plant Dis. 93:402-407.

Alternaria dauci and Cercospora carotae cause foliar blight on carrot, causing yield reductions in severely blighted fields. Currently, fungicides are used on either a 7-day schedule or according to the TOM-CAST disease forecasting system. Organic production prohibits applications of most fungicides for blight control but does allow select copper-based products. The objective of this study was to use the TOM-CAST weather forecasting system to (i) assess the efficacy of copper hydroxide treatments for organic operations and (ii) evaluate the efficacy of reduced-risk products in an alternating spray program. Chlorothalonil, azoxystrobin, and copper hydroxide were applied alone or in alternating programs in 2001 and 2002. Reapplications were made on a 7-day schedule or according to TOM-CAST using disease severity value (DSV) thresholds of 10 , 15, and 20. Area under the disease progress curve (AUDPC) data revealed that all application intervals significantly limited disease incidence on the foliage and petioles, resulting in healthier petioles at harvest compared with the untreated. The 7-day and TOM-CAST 10 DSV programs had comparable rating values for all parameters assessed and were more effective than the TOMCAST 15 and 20 DSV programs in limiting petiole disease and maintaining overall petiole health. Copper hydroxide treatments resulted in higher AUDPC values and significantly different petiole health ratings compared with other treatments, yet $P$ values indicated significant disease control compared with the untreated. The TOM-CAST 15 DSV program reduced sprays up to $40 \%$ compared with a 7-day interval and produced mean savings of $\$ 127 /$ ha in 2001 and $\$ 137 /$ ha in 2002.
\end{abstract}

Blights caused by Alternaria dauci and Cercospora carotae are common diseases of carrot (Daucus carota) in all major production areas of the world (13). Symptoms of $A$. dauci infection include dark brown, irregularly shaped lesions with a yellow margin that typically occur on mature or senescing leaves. C. carotae can infect young, emerging tissue, resulting in small, circular lesions that enlarge into dark brown spots with a chlorotic border $(17,31)$. Under environmental conditions that favor disease development, lesions coalesce to cover entire leaflets to the point of foliar necrosis and a girdling of petioles, resulting in a reduction of photosynthesis and overall yield. Because Michigan carrot growers harvest crops using mechanical equipment that grasps the foliage to lift roots out of the soil, diseased and weakened petioles break and prevent maximum harvest, thereby further reducing yield (13).

In 2006, Michigan growers harvested an estimated 2,270 ha of carrot for fresh mar-

\footnotetext{
Corresponding author: M. K. Hausbeck

E-mail: hausbec1@msu.edu
}

Accepted for publication 17 December 2008.

doi:10.1094/PDIS-93-4-0402

(C) 2009 The American Phytopathological Society ket, cut-and-peel, and processing uses (5). Depending on which of these three uses is intended, plant spacing and cultivars may vary for growers and can create challenges for management. Fungal foliar blights are currently managed by applying registered fungicides, including chlorothalonil, iprodione, azoxystrobin, pyraclostrobin, and copper-based products. Chlorothalonil and iprodione are classified as B2 carcinogens and may be impacted by the Food Quality Protection Act, as well as some processor restrictions. The strobilurin fungicide products (i.e., azoxystrobin and pyraclostrobin) offer a reduced risk to the applicator and the nontargeted environment (6). Some fixed-copper formulations are approved for use in organic crop production, according to the Organic Materials Review Institute (www.omri.org). Despite moderate control against Alternaria leaf blight when pathogen pressure is severe, copper treatments increase crop yields equivalent to several industry standard products (7).

Michigan carrot growers have shown interest in management techniques that reduce the reliance on B2 carcinogenic fungicides in order to retain future contracts with some restrictive processors, reduce production costs, and delay possible development of insensitivity of the pathogens (4). In a number of crops, focus has shifted to computerized forecasting systems that identify periods when environmental conditions favor disease. FAST and TOMCAST are examples of such a system used for diseases such as A. solani on tomato or Stemphylium vesicarium on pear, and has been shown to reduce fungicide applications from 28 to $38 \%$ compared with a 7 day schedule $(22,25)$. The TOM-CAST model reduces the required number of sprays compared with applying fungicides weekly without compromising fruit quality or yield $(11,15)$. The forecaster assigns a daily disease severity value (DSV) based on the duration of leaf wetness and the average temperature during periods with elevated moisture. When the cumulative DSV reaches a predetermined threshold, fungicide sprays are prompted (26). Studies have determined that the optimal DSVs for initiating sprays with TOM-CAST are 18 to 25 DSV for tomato $(11,20,24), 15$ DSV for purple spot ( $S$. vesicarium) on asparagus (23), and 20 and 15 DSV for Wisconsin (28) and Michigan (8), respectively, for carrot foliar blights.

Michigan carrot growers use various management practices, including disease forecasters, to control foliar blights caused by $C$. carotae and A. dauci. Organic growers may be able to include additional fungicide tools such as copper-based products into their TOM-CAST program to reduce the seasonal number of sprays. Conventional growers can incorporate reducedrisk fungicides with TOM-CAST to maintain processor standards and maximize yield. Our objective was to test the TOMCAST weather-forecasting system in combination with (i) copper hydroxide treatments for organic operations and (ii) a reduced-risk product for conventional growers seeking to reduce the use of fungicides classified as B2 carcinogens.

\section{MATERIALS AND METHODS}

Experimental design and spray applications. Plots were established at the Michigan State University Muck Soils Research Farm in Laingsburg on a Houghton muck field. Fresh market carrot seed ('Heritage') was sown at 65.6 seeds $/ \mathrm{m}$ of row on 14 May 2001 and 21 May 2002 in muck soil previously planted with potato. Three rows spaced $0.5 \mathrm{~m}$ apart were seeded per raised bed. Beds were arranged in parallel and spaced $1.6 \mathrm{~m}$ on center. Treatment plots were one bed wide and 7.2 $\mathrm{m}$ long. Sections of unsprayed carrot plants were alternated with each treatment 
plot. Twenty-nine treatments, including an untreated control, were arranged in a randomized complete block design with four blocks measuring $49.4 \mathrm{~m}$ long and $15.2 \mathrm{~m}$ wide. The susceptible cultivar used was infected by naturally occurring $C$. carotae and $A$. dauci inoculum. Weed control and fertilization requirements were managed according to standard commercial practices (33) and plots were irrigated as needed.

The fungicides copper hydroxide (Kocide 2000 53.8DF at $0.91 \mathrm{~kg}$ a.i./ha; E. I. du Pont de Nemours and Co., Wilmington, DE), chlorothalonil (Bravo Ultrex 82.5WDG at $1.30 \mathrm{~kg}$ a.i./ha; Syngenta Crop Protection, Inc., Greensboro, NC), and azoxystrobin (Quadris 2.08SC at $0.11 \mathrm{~kg}$ a.i./ha; Syngenta Crop Protection, Inc.) were applied in the following programs: (i) untreated, (ii) copper hydroxide, (iii) copper hydroxide alternated with azoxystrobin, (iv) copper hydroxide alternated with chlorothalonil; (v) azoxystrobin, (vi) azoxystrobin alternated with chlorothalonil, (vii) chlorothalonil, and (viii) chlorothalonil alternated with azoxystrobin alternated with copper hydroxide. Fungicides were applied with a $\mathrm{CO}_{2}$ backpack sprayer $(\mathrm{R} \& \mathrm{D}$ Sprayers, Opelousas, LA) equipped with three D3 hollow-cone nozzles (Teejet, Chicago) spaced $45.8 \mathrm{~cm}$ apart, operating at $2.8 \mathrm{~kg} / \mathrm{cm}^{2}$ and calibrated to deliver 473 liters/ha.

Treatments prompted according to the TOM-CAST program were based on duration of leaf wetness and average air temperature for each 24-h period (1100 to 1100) to determine a DSV value, from 0 to 4 , that corresponded to a range of unsuitable to highly suitable environmental conditions for disease development (26). After DSV threshold values were reached, prompting spray applications, the sums of daily DSV values were reset to zero. Hourly averages of leaf wetness duration and temperature were acquired using a digital data logger (WatchDog Leaf Wetness and Temperature Logger 3610TWD; Spectrum Technologies, Inc., Plainfield, IL) that was positioned northward at a $45^{\circ}$ angle and nested in the upper $75 \%$ of the crop canopy in the center of an unsprayed bed. Treatments were initiated on 29 June 2001 and 2 July 2002 at the onset of canopy closure within rows. Subsequent sprays were made at 7-day intervals or according to TOM-CAST thresholds of 10 , 15 , or $20 \mathrm{DSV}$.

Disease assessment. Foliar and petiole blight caused by $A$. dauci and $C$. carotae were assessed weekly from 2 August to 28 September 2001 and 22 July to 30 September 2002. Foliar and petiole disease assessments were based on carrot plants in the center $3 \mathrm{~m}$ of each treatment plot. Foliar blight was visually assessed according to an Alternaria leaf blight pictorial key (30) that assigns a value of $0,1,5,10$, 20 , or $40 \%$ leaf blight. Petiole blight inci- dence ( $\geq 1$ infected petioles) was determined weekly as a percentage, with disease severity estimated according to the following scale: $1=$ no lesions, $2=1$ to 5 lesions, $3=6$ to 20 lesions, $4=21$ to 50 lesions, $5=>50$ lesions per plant, 6 to $9=$ $>50$ lesions and increasing degrees of petiole necrosis, and $10=$ petiole death. At harvest on 28 September 2001 and 2 October 2002, carrot roots from the center $3 \mathrm{~m}$ of each treatment plot were hand harvested, separated from their foliage at the crown, and weighed $(\mathrm{kg})$ to determine yield. Area under the disease progress curve (AUDPC) was calculated to express the cumulative incidence of leaf and petiole infection occurring over a 57- and 70day period in 2001 and 2002, respectively, according to the method of Shaner and Finney (29).

Statistical analysis. Each year of the TOM-CAST experiment represented a randomized complete block design. Data for all variables were analyzed with an analysis of variance (ANOVA) with a linear model that included treatment, year, treatment-year, and replicate nested within year as factors using the Proc GLM procedure of the Statistical Analysis System (SAS Institute, Cary, NC). The yeartreatment interaction was not significant for any variable, so results were pooled over years. The design became a split plot in time when both years were combined. The assumptions of normality and equal variances were examined using the residuals from the ANOVA. Normality was examined using the Proc Univariate procedure of SAS. The equal variance assumption was examined using Levene's Robust Test (34) and by conducting an ANOVA on the absolute value of the residuals. All of the variables were transformed using $\mathrm{Y}=\log ($ variable +1$)$. Although the other variables did not meet both assumptions, the transformed variables improved the fit to normality in all cases.

The 29 treatments examined in this experiment represent a seven (fungicide treatments) by four (application intervals) factorial, with an untreated control as the 29th treatment. All variables had significant differences among the 29 treatments. These differences were examined by decomposing the treatment sum of squares into four component sums of squares: (i) the difference between the mean of spray treatment programs and the untreated control, (ii) differences between fungicides, (iii) differences between application intervals, and (iv) an interaction between fungicides and application intervals. The interaction between fungicide and application intervals was not significant $(P>0.05)$ for all variables. As such, the main effects of fungicide and application interval were examined using Tukey's highly significant difference to determine which fungicide or application interval had the best mean.
The variability of yield within years was notably different. As a result, yield was analyzed separately by year, using an ANOVA of a randomized complete block experiment. The ANOVA was calculated using the Proc GLM procedure of SAS, and residuals were used to examine the assumptions of normality and equal variances as noted above. Yield data met both the assumptions of normality and equal variances without transformation. Differences in mean yield between the 29 treatments were examined in the same manner as the other variables.

\section{RESULTS}

Symptoms of infection caused by $A$. dauci and C. carotae were observed 77 days after planting in 2001 and 63 days after planting in 2002 on the fresh market cv. Heritage. Within 7 weeks, $78 \%$ (2001) and $100 \%$ (2002) of the untreated petioles were blighted (Table 1), showing that disease was more severe in 2002 (approximately 50 lesions/untreated plant) than the previous year (approximately 20 lesions/untreated plant). At the final disease assessment date, untreated plants had 25 and 33\% blighted foliage in 2001 and 2002, respectively (Table 1 ).

According to AUDPC data, all application intervals significantly suppressed the incidence of disease on the foliage and petioles, resulting in healthier petioles at harvest compared with the untreated control $(P=0.0001$; Table 2$)$. The 7-day and TOM-CAST 10 DSV programs were statistically equivalent for all disease parameters measured and were more effective than the TOM-CAST 15 and 20 DSV programs in suppressing petiole disease and maintaining overall petiole health (Table 2). However, the TOM-CAST $15 \mathrm{DSV}$ program was comparable with the 7-day and TOM-CAST 10 DSV programs in managing foliar blight. TOM-CAST 20 DSV was the least effective program in maintaining overall petiole health.

All fungicide treatments significantly maintained petiole health in comparison with untreated plants. Copper hydroxide treatments resulted in higher AUDPC values and petiole health ratings compared with other fungicide treatments, yet $P$ values indicated significant disease control compared with the untreated. AUDPC values for plants treated with azoxystrobin alone, or in alternation with copper hydroxide or chlorothalonil, were similar and more favorable than other treatment combinations. Applying chlorothalonil alone was more effective than copper hydroxide in suppressing disease. Alternating chlorothalonil with copper hydroxide resulted in AUDPC values that were not significantly different than using copper hydroxide alone in controlling foliar and petiole blight.

In 2001, an assessment of petiole blight severity values, petiole blight incidence, 
and foliar blight percentages (Table 1) indicated similar control of disease across many of the fungicide treatments and application intervals, and significantly less disease than the untreated. Under heavier disease pressure than the previous year, spray programs using azoxystrobin (TOMCAST 10-DSV interval) and azoxystrobin alternated with chlorothalonil (7-day interval) suppressed petiole blight incidence $<10 \%$ of that of the untreated $(100 \%)$ in 2002. Most treatment programs suppressed foliar blight $(\%)$ compared with the untreated control in 2002, with the following exceptions: copper hydroxide applied according to TOM-CAST 15 and 20 DSV and chlorothalonil applied at TOM-CAST 20 DSV.

Weights of untreated carrot roots had a significant yield reduction compared with roots subjected to fungicide treatments in 2001 (Table 3). However, differences were not detected between treated and untreated carrot roots in 2002. An assessment of application intervals revealed that the 7 day spray program significantly increased yields compared with the TOM-CAST 15 and 20 DSV spray programs. Across fungicide programs, azoxystrobin/chlorothalonil/copper hydroxide, chlorothalonil, and azoxystrobin/copper hydroxide sprays produced the highest significant yields compared with copper hydroxide and chlorothalonil/copper hydroxide (Table 3). Although not significantly different from the other treatments, copper hydroxidetreated carrot plants had a greater yield quantity than other treatments in 2002.

The 7-day and TOM-CAST 10 DSV intervals prompted the most fungicide applications and, consequently, were the most costly programs (data not shown). The 7day spray interval prompted 13 sprays during both years, whereas the TOMCAST 10 DSV interval prompted 13 and 10 sprays for 2001 and 2002, respectively.
Although the TOM-CAST 20 DSV application interval prompted the least number of sprays, thereby reducing costs up to $50 \%$, disease control was compromised in the majority of parameters analyzed in this study. Using a TOM-CAST 15 DSV interval reduced sprays up to $40 \%$ compared with a 7-day interval and produced an average savings of $\$ 127 /$ ha in 2001 and $\$ 137 /$ ha in 2002 (data not shown).

\section{DISCUSSION}

At the time of this study, copper hydroxide was selected based on its approval for organic production systems. Many copperbased products have been regulated over the past several years based on inert ingredients. Although no longer approved as of December 2008, the copper hydroxide product used in this study will be reviewed again in spring 2009 (Marcia Martin, DuPont, personal communication). Incorporating organically approved products,

Table 1. Mean summary of petiole and foliar blight caused by Alternaria dauci and Cercospora carotae at the final rating dates in 2001 and 2002 , after applying foliar fungicides every 7-days or according to the TOM-CAST disease predictor ${ }^{\mathrm{w}}$

\begin{tabular}{|c|c|c|c|c|c|c|c|c|}
\hline \multirow[b]{3}{*}{ Treatment $^{\mathrm{z}}$} & & & \multicolumn{4}{|c|}{ Petiole blight } & & \\
\hline & \multicolumn{2}{|c|}{ No. of sprays } & \multicolumn{2}{|c|}{ Incidence $(\%)$} & \multicolumn{2}{|c|}{ Disease severity $^{x}$} & \multicolumn{2}{|c|}{ Foliar blight $(\%)^{\mathrm{y}}$} \\
\hline & 2001 & 2002 & 2001 & 2002 & 2001 & 2002 & 2001 & 2002 \\
\hline Untreated & $\ldots$ & $\ldots$ & $77.86 \mathrm{c}$ & $100.00 \mathrm{~h}$ & $2.75 \mathrm{~d}$ & $4.50 \mathrm{~g}$ & $25.00 \mathrm{c}$ & $32.50 \mathrm{f}$ \\
\hline \multicolumn{9}{|l|}{ Copper } \\
\hline 7-day & 13 & 13 & $10.05 \mathrm{ab}$ & $44.32 \mathrm{cdef}$ & $1.00 \mathrm{bc}$ & $2.25 \mathrm{abc}$ & $7.75 \mathrm{~b}$ & $5.25 \mathrm{abc}$ \\
\hline TOM-CAST $10-\mathrm{DSV}$ & 13 & 10 & $7.73 \mathrm{ab}$ & $47.04 \mathrm{def}$ & $1.00 \mathrm{bc}$ & $2.75 \mathrm{bcd}$ & $1.00 \mathrm{a}$ & $9.00 \mathrm{abc}$ \\
\hline TOM-CAST 15-DSV & 8 & 7 & $14.38 \mathrm{ab}$ & $76.82 \mathrm{gh}$ & $1.25 \mathrm{c}$ & $3.50 \mathrm{def}$ & $4.25 \mathrm{ab}$ & $22.50 \mathrm{def}$ \\
\hline TOM-CAST 20-DSV & 6 & 5 & $22.92 \mathrm{~b}$ & $78.81 \mathrm{gh}$ & $1.25 \mathrm{c}$ & $4.00 \mathrm{fg}$ & $5.75 \mathrm{ab}$ & 25.00 ef \\
\hline \multicolumn{9}{|l|}{ Azoxy/copper } \\
\hline 7-day & 13 & 13 & $1.21 \mathrm{a}$ & 27.70 bcde & $0.50 \mathrm{ab}$ & $2.00 \mathrm{ab}$ & $3.00 \mathrm{ab}$ & $3.00 \mathrm{ab}$ \\
\hline TOM-CAST $10-\mathrm{DSV}$ & 13 & 10 & $0.79 \mathrm{a}$ & $25.20 \mathrm{abcd}$ & $0.50 \mathrm{ab}$ & $2.00 \mathrm{ab}$ & $2.00 \mathrm{ab}$ & $4.00 \mathrm{ab}$ \\
\hline TOM-CAST 15-DSV & 8 & 7 & $2.65 \mathrm{a}$ & $52.63 \mathrm{efg}$ & $0.75 \mathrm{abc}$ & $2.25 \mathrm{abc}$ & $3.00 \mathrm{ab}$ & $5.25 \mathrm{abc}$ \\
\hline TOM-CAST 20-DSV & 6 & 5 & $3.89 \mathrm{a}$ & $64.27 \mathrm{fg}$ & $0.75 a b c$ & $2.75 \mathrm{bcd}$ & $3.00 \mathrm{ab}$ & $12.50 \mathrm{abcd}$ \\
\hline \multicolumn{9}{|l|}{ Chloro/copper } \\
\hline 7-day & 13 & 13 & $9.73 \mathrm{ab}$ & 29.54 abcde & $1.00 \mathrm{bc}$ & $2.25 a b c$ & $3.25 \mathrm{ab}$ & $5.75 \mathrm{abc}$ \\
\hline TOM-CAST $10-\mathrm{DSV}$ & 13 & 10 & $2.32 \mathrm{a}$ & 43.98 bcdef & $1.00 \mathrm{bc}$ & $2.25 \mathrm{abc}$ & $1.00 \mathrm{a}$ & $4.25 \mathrm{ab}$ \\
\hline TOM-CAST 15 -DSV & 8 & 7 & $2.96 \mathrm{a}$ & $69.07 \mathrm{fg}$ & $0.75 \mathrm{abc}$ & $3.00 \mathrm{cde}$ & $4.25 \mathrm{ab}$ & 14.00 abcde \\
\hline TOM-CAST 20-DSV & 6 & 5 & $15.44 \mathrm{ab}$ & $67.68 \mathrm{fg}$ & $1.25 \mathrm{c}$ & $3.00 \mathrm{cde}$ & $5.75 \mathrm{ab}$ & $10.25 \mathrm{abc}$ \\
\hline \multicolumn{9}{|l|}{ Azoxy } \\
\hline 7-day & 13 & 13 & $0.55 \mathrm{a}$ & 32.91 abcde & $0.50 \mathrm{ab}$ & $2.00 \mathrm{ab}$ & $2.00 \mathrm{ab}$ & $5.75 a b c$ \\
\hline TOM-CAST $10-\mathrm{DSV}$ & 13 & 10 & $2.23 \mathrm{a}$ & $6.29 \mathrm{a}$ & $0.75 a b c$ & $2.00 \mathrm{ab}$ & $1.00 \mathrm{a}$ & $6.75 \mathrm{abc}$ \\
\hline TOM-CAST 15 -DSV & 8 & 7 & $2.22 \mathrm{a}$ & $45.43 \mathrm{cdef}$ & $1.00 \mathrm{bc}$ & $2.25 a b c$ & $1.00 \mathrm{a}$ & $4.00 \mathrm{ab}$ \\
\hline TOM-CAST 20-DSV & 6 & 5 & $1.51 \mathrm{a}$ & 41.94 bcdef & $1.00 \mathrm{bc}$ & $2.25 \mathrm{abc}$ & $4.00 \mathrm{ab}$ & $3.25 \mathrm{ab}$ \\
\hline \multicolumn{9}{|l|}{ Azoxy/chloro } \\
\hline 7-day & 13 & 13 & $1.19 \mathrm{a}$ & $8.40 \mathrm{a}$ & $0.25 \mathrm{a}$ & $2.00 \mathrm{ab}$ & $1.00 \mathrm{a}$ & $2.00 \mathrm{a}$ \\
\hline TOM-CAST $10-\mathrm{DSV}$ & 13 & 10 & $0.76 \mathrm{a}$ & $10.85 \mathrm{a}$ & $0.75 \mathrm{abc}$ & $2.00 \mathrm{ab}$ & $2.00 \mathrm{ab}$ & $2.00 \mathrm{a}$ \\
\hline TOM-CAST 15-DSV & 8 & 7 & $1.07 \mathrm{a}$ & $50.36 \mathrm{defg}$ & $0.50 \mathrm{ab}$ & $2.25 a b c$ & $2.00 \mathrm{ab}$ & $4.25 \mathrm{ab}$ \\
\hline TOM-CAST 20-DSV & 6 & 5 & $2.51 \mathrm{a}$ & $50.44 \mathrm{defg}$ & $0.75 a b c$ & $2.75 \mathrm{bcd}$ & $4.25 \mathrm{ab}$ & $16.25 \mathrm{cde}$ \\
\hline \multicolumn{9}{|l|}{ Chloro } \\
\hline 7-day & 13 & 13 & $1.47 \mathrm{a}$ & $17.84 \mathrm{abc}$ & $0.75 a b c$ & $1.75 \mathrm{a}$ & $1.00 \mathrm{a}$ & $3.25 \mathrm{ab}$ \\
\hline TOM-CAST $10-\mathrm{DSV}$ & 13 & 10 & $1.97 \mathrm{a}$ & $12.03 \mathrm{a}$ & $0.50 \mathrm{ab}$ & $1.75 \mathrm{a}$ & $0.75 \mathrm{a}$ & $1.00 \mathrm{a}$ \\
\hline TOM-CAST $15-\mathrm{DSV}$ & 8 & 7 & $4.86 \mathrm{a}$ & 32.23 abcde & $0.75 \mathrm{abc}$ & $2.50 \mathrm{abc}$ & $2.00 \mathrm{ab}$ & $10.50 \mathrm{abc}$ \\
\hline TOM-CAST 20-DSV & 6 & 5 & $7.27 \mathrm{a}$ & $64.40 \mathrm{fg}$ & $1.00 \mathrm{bc}$ & $3.75 \mathrm{efg}$ & $3.00 \mathrm{ab}$ & $30.25 \mathrm{f}$ \\
\hline \multicolumn{9}{|l|}{ Azoxy/chloro/copper } \\
\hline 7 -day & 13 & 13 & $0.57 \mathrm{a}$ & 26.71 abcde & $0.50 \mathrm{ab}$ & $2.00 \mathrm{ab}$ & $2.00 \mathrm{ab}$ & $6.25 \mathrm{abc}$ \\
\hline TOM-CAST $10-\mathrm{DSV}$ & 13 & 10 & $0.70 \mathrm{a}$ & $15.50 \mathrm{ab}$ & $0.50 \mathrm{ab}$ & $2.00 \mathrm{ab}$ & $1.00 \mathrm{a}$ & $3.00 \mathrm{ab}$ \\
\hline TOM-CAST 15 -DSV & 8 & 7 & $2.38 \mathrm{a}$ & $11.87 \mathrm{a}$ & $0.75 \mathrm{abc}$ & $2.00 \mathrm{ab}$ & $2.00 \mathrm{ab}$ & $2.00 \mathrm{a}$ \\
\hline TOM-CAST 20-DSV & 6 & 5 & $2.34 \mathrm{a}$ & $67.13 \mathrm{fg}$ & $0.75 \mathrm{abc}$ & 3.00 cde & $4.25 \mathrm{ab}$ & $9.00 \mathrm{abc}$ \\
\hline
\end{tabular}

${ }^{\text {w }}$ Means within a column followed by the same letter are not significantly different according to Fisher's least significant difference $(\alpha=0.05)$.

${ }^{x}$ Cumulative incidence of petiole disease severity, pooled over 2001 and 2002 , according to the following rating scale: $1=$ no lesions, $2=1-5$ lesions, $3=6-$ 20 lesions, $4=21-50$ lesions, and $5=>50$ lesions per plant, $6-9=>50$ lesions and increasing degrees of petiole necrosis, and $10=$ petiole death.

${ }^{y}$ Severity was visually assessed using an Alternaria leaf blight pictorial key that assigns values of $0,1,5,10,20$, or $40 \%$ leaf blight.

${ }^{\mathrm{z}}$ Duration of leaf wetness and ambient temperature for 24-h intervals, which determines a disease severity value (DSV) that corresponds to varying conditions suitable for disease development. Treatment (a.i./ha): copper hydroxide (Copper) at $0.91 \mathrm{~kg}$, azoxystrobin (Azoxy) at $0.11 \mathrm{~kg}$, and chlorothalonil (Chloro) at $1.3 \mathrm{~kg}$. 
which should be referenced at the Organic Materials Review Institute prior to use, with a TOM-CAST weather forecasting system would allow growers to manage foliar blight in conjunction with other management and cultivation tactics, to compete with the rapidly growing organic segment of U.S. agriculture (3).

Using reduced risk (i.e., azoxystrobin) and biocontrol products to control foliar diseases on carrot offers an alternative to relying on fungicides containing B2 carcinogens. Despite this, biological agents like harpin protein and Bacillus subtilis did not show consistent control in different evaluations, especially against Cercospora leaf blight $(12,27)$. Compost teas are another reduced-risk alternative where plantpathogenic organisms were shown to have been suppressed when extracts are applied directly to plant surfaces $(10,32)$, yet a Michigan study in 2004 proved that, when compost tea was applied every 7 days, foliar blight on carrot was not significantly limited (14).

Already integrated as a management tool by Michigan growers (8), the TOMCAST program has effectively reduced grower reliance on spraying prematurely or too frequently, thereby decreasing seasonal costs $(8,28)$. In our study, the TOM-CAST 10 DSV program only differed from the weekly spray interval in 2002 , with 10 sprays triggered compared with 13 . According to Table 2 data, this program had statistically similar results to the 7-day program for petiole blight incidence, petiole health, and foliar blight. TOM-CAST at 15 DSV prompted 8 (2001) and 7 (2002) sprays compared with the 13 used by the calendar-based weekly interval, cutting spray costs by $\$ 55$ and $\$ 66 /$ ha, respectively. Similarly, Rogers and Stevenson (28) showed that using the TOM-CAST 15

DSV program allowed them to reduce sprays by four compared to the 7-day interval. Bounds et al. (8) also confirmed that the 15 DSV program prompted fewer sprays (between five and seven) than the 7 day program. Despite the TOM-CAST 20

Table 3. Average weight $(\mathrm{kg})$ of carrot roots harvested during 2001 and 2002 growing seasons after applying foliar fungicides every 7 days or according to the TOM-CAST disease predictor ${ }^{\mathrm{v}}$

\begin{tabular}{|c|c|c|c|c|c|c|}
\hline \multirow[b]{2}{*}{ Treatment $^{w}$} & \multicolumn{6}{|c|}{ Yield $(\mathrm{kg}) / \mathbf{3} \mathrm{m}$} \\
\hline & $2001^{x}$ & $F$ value & $P$ value & $2002^{y}$ & $F$ value & $P$ value \\
\hline \multicolumn{7}{|l|}{ Application interval } \\
\hline 7-day & $13.02 \mathrm{~b}$ & $\ldots$ & $\ldots$ & $14.08 \mathrm{a}$ & $\ldots$ & $\ldots$ \\
\hline TOM-CAST 10 DSV & $12.67 \mathrm{ab}$ & $\ldots$ & $\ldots$ & $13.23 \mathrm{a}$ & $\ldots$ & $\ldots$ \\
\hline TOM-CAST 15 DSV & $12.22 \mathrm{a}$ & $\ldots$ & $\ldots$ & $14.00 \mathrm{a}$ & $\ldots$ & $\ldots$ \\
\hline TOM-CAST 20 DSV & $12.18 \mathrm{a}$ & $\ldots$ & $\ldots$ & $13.30 \mathrm{a}$ & $\ldots$ & $\ldots$ \\
\hline \multicolumn{7}{|l|}{ Fungicide } \\
\hline Copper & $11.60 \mathrm{a}$ & $\ldots$ & $\ldots$ & $14.75 \mathrm{a}$ & $\ldots$ & $\ldots$ \\
\hline Azoxy/copper & $13.02 \mathrm{~b}$ & $\ldots$ & $\ldots$ & $13.88 \mathrm{a}$ & $\ldots$ & $\ldots$ \\
\hline Chloro/copper & $11.55 \mathrm{a}$ & $\ldots$ & $\ldots$ & $13.86 \mathrm{a}$ & $\ldots$ & $\ldots$ \\
\hline Azoxy & $12.44 \mathrm{ab}$ & $\ldots$ & $\ldots$ & $13.53 \mathrm{a}$ & $\ldots$ & $\ldots$ \\
\hline Azoxy/chlorol & $12.73 \mathrm{~b}$ & $\ldots$ & $\ldots$ & $13.53 \mathrm{a}$ & $\ldots$ & $\ldots$ \\
\hline Chloro & $13.05 \mathrm{~b}$ & $\ldots$ & $\ldots$ & $13.11 \mathrm{a}$ & $\ldots$ & $\ldots$ \\
\hline Azoxy/chloro/copper & $13.26 \mathrm{~b}$ & $\ldots$ & $\ldots$ & $12.60 \mathrm{a}$ & $\ldots$ & $\ldots$ \\
\hline \multicolumn{7}{|l|}{ Contrast } \\
\hline Untreated & $\ldots$ & 25.02 & $<0.0001$ & $\ldots$ & 0.12 & 0.7290 \\
\hline Fungicide & $\ldots$ & 6.77 & $<0.0001$ & $\ldots$ & 1.97 & 0.0790 \\
\hline Application interval & $\ldots$ & 3.84 & 0.0125 & $\ldots$ & 1.65 & 0.1847 \\
\hline Fungicide-interval $^{\mathrm{z}}$ & $\ldots$ & 1.61 & 0.0756 & $\ldots$ & 0.69 & 0.8325 \\
\hline
\end{tabular}

${ }^{\mathrm{v}}$ Means within a column followed by the same letter or no letter are not significantly different according to Tukey's highly significant difference $(\alpha=0.05)$.

${ }^{w}$ Duration of leaf wetness and ambient temperature for $24 \mathrm{~h}$ intervals, which determines a disease severity value (DSV) that corresponds to varying conditions suitable for disease development. Treatment (a.i./ha): copper hydroxide (Copper) at $0.91 \mathrm{~kg}$, azoxystrobin (Azoxy) at $0.11 \mathrm{~kg}$, and chlorothalonil (Chloro) at $1.3 \mathrm{~kg}$.

${ }^{x}$ In 2001 , untreated yield $(8.72 \mathrm{~kg})$ differed significantly from the other treatments $(P=0.0001)$.

${ }^{y}$ In 2002 , untreated yield $(10.71 \mathrm{~kg})$ did not differ significantly from the other treatments $(P=$ 0.7290).

${ }^{\mathrm{z}}$ Fungicide-application interval interaction.

Table 2. Evaluation of fungicide applications (appl.) against Alternaria dauci and Cercospora carotae using different disease thresholds based on a TOMCAST forecasting system on 'Heritage' carrot ${ }^{\mathrm{v}}$

\begin{tabular}{|c|c|c|c|c|c|c|c|c|c|c|c|}
\hline \multirow[b]{2}{*}{ Treatment $^{y}$} & \multicolumn{2}{|c|}{ No. of appl. } & \multicolumn{6}{|c|}{ AUDPC (disease-day) ${ }^{w}$} & \multicolumn{3}{|c|}{ Petiole disease severity ${ }^{x}$} \\
\hline & 2001 & 2002 & Petiole & $F$ value & $P$ value & Foliar & $F$ value & $P$ value & Severity & $F$ value & $P$ value \\
\hline \multicolumn{12}{|l|}{ Application interval } \\
\hline 7-day & 13 & 13 & $53.83 \mathrm{a}$ & $\ldots$ & $\ldots$ & $52.63 \mathrm{a}$ & $\ldots$ & $\ldots$ & $3.39 \mathrm{a}$ & $\ldots$ & $\ldots$ \\
\hline TOM-CAST 10 DSV & 13 & 10 & $54.92 \mathrm{a}$ & $\ldots$ & $\ldots$ & 49.39 a & $\ldots$ & $\ldots$ & $3.43 \mathrm{a}$ & $\ldots$ & $\ldots$ \\
\hline TOM-CAST 15 DSV & 8 & 7 & $122.25 \mathrm{~b}$ & $\ldots$ & $\ldots$ & $70.51 \mathrm{ab}$ & $\ldots$ & $\ldots$ & $4.02 \mathrm{~b}$ & $\ldots$ & $\ldots$ \\
\hline TOM-CAST 20 DSV & 6 & 5 & $219.70 \mathrm{~b}$ & $\ldots$ & $\ldots$ & $104.65 \mathrm{~b}$ & $\ldots$ & $\ldots$ & $4.88 \mathrm{c}$ & $\ldots$ & $\ldots$ \\
\hline \multicolumn{12}{|l|}{ Fungicide } \\
\hline Copper & $\ldots$ & $\ldots$ & $359.90 \mathrm{c}$ & $\ldots$ & $\ldots$ & $149.39 \mathrm{~b}$ & $\ldots$ & $\ldots$ & $5.13 \mathrm{~b}$ & $\ldots$ & $\ldots$ \\
\hline Azoxy/copper & $\ldots$ & $\ldots$ & $67.36 \mathrm{ab}$ & $\ldots$ & $\ldots$ & $63.42 \mathrm{ab}$ & $\ldots$ & $\ldots$ & $3.72 \mathrm{a}$ & $\ldots$ & $\ldots$ \\
\hline Chloro/copper & $\ldots$ & $\ldots$ & $162.99 \mathrm{bc}$ & $\ldots$ & $\ldots$ & $86.72 a b$ & $\ldots$ & $\ldots$ & $4.13 \mathrm{a}$ & $\ldots$ & $\ldots$ \\
\hline Azoxy & $\ldots$ & $\ldots$ & $85.30 \mathrm{ab}$ & $\ldots$ & $\ldots$ & $48.41 \mathrm{a}$ & $\ldots$ & $\ldots$ & $3.75 \mathrm{a}$ & $\ldots$ & $\ldots$ \\
\hline Azoxy/chloro & $\ldots$ & $\ldots$ & $47.24 \mathrm{a}$ & $\ldots$ & $\ldots$ & $50.90 \mathrm{a}$ & $\ldots$ & $\ldots$ & $3.97 \mathrm{a}$ & $\ldots$ & $\ldots$ \\
\hline Chloro & $\ldots$ & $\ldots$ & $84.29 \mathrm{ab}$ & $\ldots$ & $\ldots$ & $54.33 \mathrm{a}$ & $\ldots$ & $\ldots$ & $3.44 \mathrm{a}$ & $\ldots$ & $\ldots$ \\
\hline Azoxy/chloro/copper & $\ldots$ & $\ldots$ & $50.27 \mathrm{a}$ & $\ldots$ & $\ldots$ & $50.43 \mathrm{a}$ & $\ldots$ & $\ldots$ & $3.38 \mathrm{a}$ & $\ldots$ & $\ldots$ \\
\hline \multicolumn{12}{|l|}{ Contrasts } \\
\hline Untreated & $\ldots$ & $\ldots$ & $\ldots$ & 40.58 & $<0.0001$ & $\ldots$ & 107.33 & $<0.0001$ & $\ldots$ & 11.43 & $<0.0001$ \\
\hline Fungicide & $\ldots$ & $\ldots$ & $\ldots$ & 7.38 & $<0.0001$ & $\ldots$ & 13.40 & $<0.0001$ & $\ldots$ & 8.74 & $<0.0001$ \\
\hline Interval & $\ldots$ & $\ldots$ & $\ldots$ & 11.52 & $<0.0001$ & $\ldots$ & 16.19 & $<0.0001$ & $\ldots$ & 21.73 & $<0.0001$ \\
\hline Fungicide-interval $^{\mathrm{z}}$ & $\ldots$ & $\ldots$ & $\ldots$ & 0.59 & 0.9037 & $\ldots$ & 1.35 & 0.1613 & $\ldots$ & 1.28 & 0.2068 \\
\hline
\end{tabular}

${ }^{v}$ Mean values were pooled over 2001 and 2002. Means within a column followed by the same letter are not significantly different according to Tukey's highly significant difference $(\alpha=0.05)$.

${ }^{\mathrm{w}}$ Cumulative incidence of leaf and petiole infection expressed as area under the disease progress curve (AUDPC) for petiole blight incidence (Petiole) and foliar blight (Foliar).

${ }^{x}$ Cumulative incidence of petiole disease severity, pooled over 2001 and 2002, according to the following rating scale: $1=$ no lesions, $2=1-5$ lesions, $3=6-$ 20 lesions, $4=21-50$ lesions, and 5 = >50 lesions per plant, $6-9=>50$ lesions and increasing degrees of petiole necrosis, and $10=$ petiole death.

${ }^{y}$ Duration of leaf wetness and ambient temperature for 24-h intervals, which determines a disease severity value (DSV) that corresponds to varying conditions suitable for disease development. Treatment (a.i./ha): copper hydroxide (Copper) at $0.91 \mathrm{~kg}$, azoxystrobin (Azoxy) at $0.11 \mathrm{~kg}$, and chlorothaloni (Chloro) at $1.3 \mathrm{~kg}$.

${ }^{\mathrm{z}}$ Fungicide-interval interaction. 
DSV triggering less than half the sprays of the 7-day program, unacceptable disease control resulted. When environmental conditions are favorable for disease to occur early and progress rapidly, as in our 2002 study, application intervals may need to be shortened to a 7-day or TOM-CAST 10 DSV program. In such situations, reducing the number of sprays may still be obtainable when using effective scouting methods and initiating sprays based on trace amounts of foliar blighting, as Bounds et al. (9) validated when screening varying disease thresholds in conjunction with TOM-CAST.

Carrot growers experience yield losses when the petioles become weakened. During mechanical harvesting, machinery that lifts the roots by grasping the foliage will cause diseased petioles to snap, leaving unharvested roots in the ground (33). Despite not experiencing an effect of treatment programs, we recorded that fungicide-treated plot yields were $31 \%$ (2001) and $22 \%$ (2002) higher compared with untreated plots. Langenberg (21) discussed a correlation between yield reduction and leaf blight severity, caused by $A$. dauci, in a study that showed that a progressively higher percentage of mechanically harvested plants had snapped at the petiole as leaf blighting increased above $10 \%$. In 2001 of our study, foliar blighting was limited to $\leq 7.75 \%$ with fungicide treatment programs. However, in 2002, we saw that multiple fungicide treatments under the TOM-CAST 15 and 20 DSV programs exceeded the $10 \%$ threshold of foliar blighting highlighted by Langenberg (21), which may have affected yield losses during a mechanical harvest (Table 1). Similarly, petiole blight severity in 2002 was $50 \%$ higher than the previous year, which may explain the insignificant yield totals compared with the untreated (Table 3 ).

Based on grower surveys in Michigan and Wisconsin (M. K. Hausbeck, unpublished data), chlorothalonil is the primary foliar fungicide used on commercially grown carrot to manage $A$. dauci and $C$. carotae. In order to minimize toxicity to nontarget organisms and the environment, our study evaluated the efficacy of alternating chlorothalonil sprays with a reducedrisk product. Similar studies in Michigan, Indiana, and Maryland were successful in their investigations, whereby the TOMCAST system prompted fewer applications of chlorothalonil to control A. solani and Stemphylium lycopersici on marketable yields of tomato $(11,24)$. Based on our AUDPC and petiole disease severity data, alternating azoxystrobin with either copper hydroxide or chlorothalonil significantly controlled disease at a commercially acceptable level, which has been corroborated by other studies (12,17-19). A spray program alternating all three products was equally effective for all parameters assessed under a 7-day interval, which re- duces exposure to carcinogenic ingredients. Moreover, growers can further reduce toxicity exposure when alternations are combined with a TOM-CAST DSV program that could prompt fewer sprays. This was substantiated by Rogers and Stevenson (28) when they alternated azoxystrobin and chlorothalonil on a TOM-CAST 15 and 20 DSV spray schedule, showing that toxicity values were reduced by 55 to $80 \%$ when compared with a 7-day schedule using chlorothalonil alone.

As a result of the final ruling of the $\mathrm{Na}$ tional Organic Program, organic carrot producers are able to use copper-based products, as outlined by the United States Department of Agriculture, as long as users minimize copper accumulation in the soil. In this study, we observed less control of lone applications of copper hydroxide compared with the other fungicides. Despite this, our AUDPC data shows that it was significantly better in controlling disease progression than the untreated under the 7-day and TOM-CAST 10 DSV spray programs. Furthermore, using a copperbased fungicide is inexpensive (costing $50 \%$ less than chlorothalonil) and does provide a certain degree of control when compared with the absence of treatment, which has been validated by several other studies on carrot crops $(1,2,7,16)$. A 2001 study by Ben-Noon et al. (7) shows that copper hydroxide treatments significantly controlled $A$. dauci up to $55 \%$ better than the untreated. Additional examples of foliar blight control with copper hydroxide can be seen in reports by Abawi and Ludwig (1), where average leaf blight severity was reduced by 40 to $50 \%$ compared with the untreated plants. Although trends were observed, these researchers saw a decline in efficacy in 2003 and 2004 compared with earlier studies. These differences could be attributed to the frequent rainfall experienced in Geneva, NY over the duration of their experiments, which often occurred within 1 to $4 \mathrm{~h}$ following fungicide applications $(2,16)$.

Managing foliar blights on carrot requires multiple management tactics used concurrently. TOM-CAST has shown the potential to significantly reduce the number of fungicide applications necessary to provide economic control of foliar blight on Michigan carrot operations. If this forecasting system is integrated with other substantiated measures, growers can maximize their pest management strategies more efficiently. Because it is standard practice for Michigan carrot growers to routinely scout for pests, prolonging spray initiation until trace amounts of foliar blight is found can reduce the number of applications from one to five while providing a savings of up to $\$ 140 / \mathrm{ha}$, as was confirmed by Bounds et al. (9). When carrot growers combine these management practices with planting disease-resistant cultivars, they may be able to reduce their seasonal costs of controlling foliar blight more than if utilizing a single tactic. Future management studies may continue to screen other organically approved fungicidal materials or other reduced risk fungicides, with differing modes of action, to avoid reliance on a particular mode of action.

\section{ACKNOWLEDGMENTS}

This material is based upon work supported by the United States Department of Agriculture, Cooperative State Research, Education, and Extension Service Risk Avoidance and Mitigation Program award number 00-51101-9594. We thank the Michigan carrot growers for their support, B. Cortright for field support, and S. Linderman for aid in manuscript preparation.

\section{LITERATURE CITED}

1. Abawi, G. S., and Ludwig, J. W. 2003. Evaluation of fungicides for control of leaf blights on carrot, 2002. Fungic. Nematicide Tests (online). Report 58:V015. DOI:10.1094/FN58. The American Phytopathological Society, St. Paul, MN.

2. Abawi, G. S., and Ludwig, J. W. 2004. Evaluation of fungicides for control of leaf blights on carrot, 2003. Fungic. Nematicide Tests (online). Report 59:V044. DOI:10.1094/FN59. The American Phytopathological Society, St. Paul, MN.

3. Anonymous. 2008. Organic production. U. S. Dep. Agric. Econ. Res. Serv. Data Sets. Online publication.

4. Anonymous. 2008. Pest management in the future: a strategic plan for the Michigan carrot industry. U. S. Dep. Agric. Integrated Pest Management Centers, Center Products. Online publication.

5. Anonymous. 2008. Vegetables Annual Summary, 01.26.2007. U. S. Dep. Agric. Natl. Agric. Stat. Serv. Online publication.

6. Bartlett, D. W., Clough, J. M., Godwin, J. R. Hall, A. A., Hamer, M., and Parr-Dobrzanski, B. 2002. Review: the strobilurin fungicides. Pest Manage. Sci. 58:649-662.

7. Ben-Noon, E., Shtienberg, D., Shlevin, E. Vintal, H., and Dinoor, A. 2001. Optimization of chemical suppression of Alternaria dauci, the causal agent of Alternaria leaf blight in carrots. Plant Dis. 85:1149-1156.

8. Bounds, R. S., Hausbeck, M. K., and Podolsky, R. H. 2006. Comparing disease forecasters for timing fungicide sprays to control foliar blight on carrot. Plant Dis. 90:264-268. DOI: 10.1094/PD-90-0264.

9. Bounds, R. S., Podolsky, R. H., and Hausbeck, M. K. 2007. Integrating disease thresholds with TOM-CAST for carrot foliar blight management. Plant Dis. 91:798-804. DOI: 10.1094/PDIS-91-7-0798.

10. Brinton, W. F., Trankner, A., and Droffner, M 1996. Investigations into liquid compost extracts. BioCycle 37:68-70.

11. Byrne, J. M., Hausbeck, M. K., and Latin, R. X. 1997. Efficacy and economics of management strategies to control anthracnose fruit rot in processing tomatoes in the Midwest. Plant Dis. 81:1167-1172.

12. Carroll, J. E., Ludwig, J. W., and Abawi, G. S. 2002. Evaluation of fungicides for control of leaf blight on carrot, 2001. Fungic. Nematicide Tests (online). Report 57:V018. DOI:10.1094/ FN57. The American Phytopathological Society, St. Paul, MN.

13. Davis, R. M., and Raid, R. N., eds. 2002 Compendium of Umbelliferous Crop Diseases, The Disease Compendium Series. American Phytopathological Society Press, St. Paul, MN.

14. Dorman, E. A., and Hausbeck, M. K. 2004 
Evaluation of soil and foliar applications of organic products for control of foliar blights on carrot, 2001. Biol. Cult. Tests (online). Report 19:V013. DOI:10.1094/BC19. The American Phytopathological Society, St. Paul, MN.

15. Gleason, M. L., McNab, A. A., Pitblado, R. E., Ricker, M. D., East, D. A., and Latin, R. X. 1995. Disease-warning systems for processing tomatoes in eastern North America: are we there yet? Plant Dis. 79:113-121.

16. Gugino, B. K., Ludwig, J. W., and Abawi, G. S. 2005. Evaluation of fungicides for management of leaf blight on carrot, 2004. Fungic. Nematicide Tests (online). Report 60:V081. DOI:10.1094/FN60. The American Phytopathological Society, St. Paul, MN.

17. Hausbeck, M. K., Cortright, B. D., and Linderman, S. D. 2000. Chemical control of Alternaria blight in carrot, 1999. Fungic. Nematicide Tests (online). Report 55:153-154. DOI:10.1094/FN55. The American Phytopathological Society, St. Paul, MN.

18. James, R. V., Stevenson, W. R., and Rand, R. E. 2000. Evaluation of selected fungicides to control carrot foliar blights-Hancock, 1999.

Fungic. Nematicide Tests (online). Report 55:155. DOI:10.1094/FN55. The American Phytopathological Society, St. Paul, MN.

19. James, R. V., Stevenson, W. R., and Rand, R. E. 2001. Evaluation of fungicides to control carrot foliar blights, 2000. Fungic. Nematicide Tests (online). Report 56:V6. DOI:10.1094/FN56. The American Phytopa- thological Society, St. Paul, MN

20. Keinath, A. P., DuBose, V. B., and Rathwell, P. J. 1996. Efficacy and economics of three fungicide application schedules for early blight control and yield of fresh-market tomato. Plant Dis. 80:1277-1282.

21. Langenberg, W. J. 1975. Carrot leaf blight (Alternaria dauci) development in relation to environmental factors and fungicide applications. M.S. thesis, University of Guelph, Ontario, Canada.

22. Madden, L., Pennypacker, S. P., and McNab, A. A. 1978. FAST, a forecast system for Alternaria solani on tomato. Phytopathology 68:1354-1358.

23. Meyer, M. P., Hausbeck, M. K., and Podolsky, R. 2000. Optimal fungicide management of purple spot of asparagus and impact on yield. Plant Dis. 84:525-530.

24. Mills, D. J., Coffman, C. B. Teasdale, J. R., Everts, K. L., Abdul-Baki, A. A., Lydon, J., and Anderson, J. D. 2002. Foliar disease in fresh-market tomato grown in different bed strategies and fungicide spray programs. Plant Dis. 86:955-959.

25. Montesinos, E. 1992. Evaluation of FAST as a forecasting system for scheduling fungicide sprays for control of Stemphylium vesicarium on pear. Plant Dis. 76:1221-1226.

26. Pitblado, R. E. 1992. The Development and Implementation of TOM-CAST. Ontario Ministry of Agriculture and Food, Ridgetown, Canada.
27. Rogers, P. M., James, R. V., Stevenson, W. R., and Rand, R. E. 2002. Evaluation of fungicides to control carrot foliar blights, 2001. Fungic. Nematicide Tests (online). Report 57:V021. DOI:10.1094/FN57. The American Phytopathological Society, St. Paul, MN.

28. Rogers, P. M., and Stevenson, W. R. 2006. Weather-based fungicide spray programs for control of two foliar diseases on carrot cultivars differing in susceptibility. Plant Dis. 90:358-364. Plant Dis. 90:358-364. DOI: 10.1094/PD-90-0358.

29. Shaner, G., and Finney, R. E. 1977. The effect of nitrogen fertilization on the expression of slow-mildewing resistance in Knox wheat. Phytopathology 67:1051-1056.

30. Strandberg, J. O. 1988. Establishment of Alternaria leaf blight on carrots in controlled environments. Plant Dis. 72:522-526.

31. Thomas, H. R. 1943. Cercospora blight of carrot. Phytopathology 33:114-125.

32. Weltzien, H. C. 1991. Biocontrol of foliar fungal diseases with compost extracts. Pages 430-450 in: Microbial Ecology of Leaves. Brock Springer Series in Contemporary Bioscience. J. H. Andrews and S. S. Hirano, eds. Springer-Verlag, New York.

33. Zandstra, B. H., Warncke, D. D., Grafius, E. J. and Lacy, M. L. 1986. Commercial Vegetable Recommendations: Carrots. Mich. State Univ. Ext. Bull. E-1437, East Lansing, MI.

34. Zar, J. H. 1996. Biostatistical Analysis. Prentice Hall, Upper Saddle River, NJ. 